\title{
CZARNE SEZONY. CZARNE LATAWCE. O DZIECIĘCYCH BIBLIOTEKACH W GETTACH
}

Słowa kluczowe: Zagłada, lektury w gettach, dziecko, style odbioru Keywords: Holocaust, the reading in ghettos, child, the styles of reception

\section{BLACK SEASONS. BLACK KITES. ABOUT THE CHILDREN'S READING IN GHETTOS}

\section{S u m m a r y}

The article Black Seasons. Black Kites. About the Children's Reading in Ghettos is devoted to the Holocaust seen and lived from the perspective of children. The author is interested in book collections of those who survived the war and later became writers (U. Orlev, A. Frankel, and M. Głowiński), and those stories that thematise children's reading in ghettos (D. Combrzyńska-Nogala, M. Szczygielski). Joanna Roszak shows which books became for the children readers a matrix imposed on reality, which met the needs of a library therapy, helped children to cope with the emotional challenges of ghetto existence, and which enabled integration and identification processes. Moreover, the authoress presents which books triggered the escapist interpretation and finally which found an extension in the stories and essays created after the war. The title of the paper refers to The Black Seasons [Czarne sezony] by Michał Głowiński, and to a line from Czesław Miłosz's Campo di Fiori.

Co czyta ludność? Temat ten ciekawi każdego Żyda, a po wojnie będzie interesowat świat. Emanuel Ringelblum, czerwiec 1942

Zwykli ludzie nie wiedza, ile dla kogoś zamkniętego znacza książki. Anne Frank, Dziennik

To będzie noc w głębokim śniegu który ma moc gtuszenia kroków [...] jeśli nas nie wyśledza wilki i człowiek $w$ szubie co kotysze na piersi szybkostrzelna śmierć poderwać trzeba się i biec w oklasku suchym krótkich salw na tamten upragniony brzeg Zbigniew Herbert, Odpowiedż 


\section{Daleko}

Samuel D. Kassow słusznie zauważył, że to los dzieci „wydobywał ze społecz-

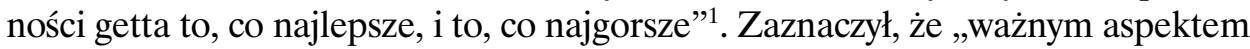
[...] walki o żydowskie dziecko było podtrzymywanie morale. Wiele dzieci całkowicie już zapomniało, jak wyglądają rzeki, wzgórza, lasy czy parki" ${ }^{2}$. Czytanie mogło uruchomić ich wspomnienia lub - w przypadku młodszych, niepamiętających życia poza murami - wyobraźnię. Amerykański historyk przytoczył w tym kontekście wiersz Rozmowa $z$ dzieckiem Władysława Szlengla, poety getta:

Lecz jak wytłumaczyć dziecku,

co znaczy słowo: daleko...

Gdy nie wie, co to jest góra.

I nie wie, co zwie się rzeką...

I nie wie jak matka... i nie ma jak ja

Obrazów tych pod powieką,

Więc jak wytłumaczyć dziecku,

co znaczy słowo daleko³.

Dzieci nierzadko docierały do takich dalekich krain, sięgając po książkę, jak po wehikuł czasu. Owo „daleko” wspominał Michał Głowiński, właśnie w rozdziale poświęconym czytaniu:

Pierwszy to opasła księga szachowa, zawierająca zapisy słynnych partii. [...] A skarbem drugim był wielki niemiecki atlas, pochodzący chyba jeszcze $\mathrm{z}$ okresu przedhitlerowskiego, $\mathrm{w}$ wielkim formacie [...]. Rozkładałem go na podłodze i przyglądałem się światu. Komentarzy i legend oczywiście nie rozumiałem, ale samo oglądanie map mi wystarczyło, pobudzało fantazję i marzenia o tym, co jest daleko („daleko” znaczyło zresztą często „za murami”)

Artykuł odsłoni, które lektury stawały się dla dziecięcych czytelników matrycą nakładaną na rzeczywistość, które pozwalały budować zespół interpretacji umożliwiających procesy zestrajające, odczytania autoidentyfikacyjne, rekontekstualizujące, lustrzane, eskapistyczne, jakie książki zaspokajały potrzeby biblioterapeutyczne, pomagały dzieciom radzić sobie z emocjonalnymi wyzwaniami egzystencji w getcie, które zaś tytuły dodatkowo znalazły przedłużenie w fabułach i esejach tworzonych po wojnie ${ }^{5}$. Interesują mnie księgozbiory zamkniętych w gettach

${ }^{1}$ Samuel D. Kassow, Kto napisze nasza historię. Ukryte Archiwum Emanuela Ringelbluma. Ostatni rozdział zagłady warszawskiego getta, trans. Grażyna Waluga, Olga Zienkiewicz (Warszawa: Amber, 2009), 243.

${ }^{2}$ Ibidem, 249.

${ }^{3}$ Cit. per ibidem, 249-250.

${ }^{4}$ Michał Głowiński, Czarne sezony (Warszawa: Open, 1998), 159.

${ }^{5}$ Cf. Joanna Roszak, „The Remains of the Letters. Three Reading Paradigms in the Ghettos”, Porównania, no. 21 (2017): 225-241. 
dzieci, a zatem szerzej: zajmuje mnie Zagłada widziana i przeżywana z dziecięcej perspektywy. Sprzęgają się tu dwa zakresy tematyczne: wątek biblioteczek tych dzieci, które przeżyły wojnę, a po niej zostały pisarzami, oraz fabuły tematyzujące dziecięce czytanie w gettach i jednocześnie przeznaczone prymarnie dla młodych czytelników ${ }^{6}$. Interesować będzie mnie zatem, które książki zostają w getcie „aktualizowane przez czytelnika” (Hans Robert Jauss) ${ }^{7}$.

\section{Czarne latawce}

Jest w filmie $A z y l$ (2017) scena, w której Antonina Żabińska z synem wychodzą na taras willi ulokowanej na terenie warszawskiego zoo i - niczym czarny śnieg - opadają na ich twarze strzępy palonych w getcie książek. Mamy 19 kwietnia 1943 roku. Oglądający ten obraz przypomina sobie zapewne wersy Czesława Miłosza: „Czasem wiatr z domów płonących / Przynosił czarne latawce”. Nasuwają się pytania, o czym opowiadały te palone listy i książki, jakie zawierały dedykacje i ekslibrisy, co zanotowano na ich marginesach, które zdania w nich podkreślono, z ilu rąk do ilu innych rąk je przekazywano? Tytuł niniejszego artykułu nawiązuje zarówno do Campo di Fiori, jak i do Czarnych sezonów Michała Głowińskiego.

Ryszard Krynicki w wierszu Jakie to szczęście opisał spotkanie z Żydem na Dworcu Centralnym. Poeta przywołał obraz strzępów spalonego papieru, kojarzący się z opisami żydowskich pogrzebów zniszczonych, rozsypujących się książek, składanych w bożnicy do skrzyni i wynoszonych na cmentarz 9 .

${ }^{6} \mathrm{~W}$ artykule nie zostanie podjęty temat książek wybieranych przez młodych autorów gettowch dzienników - te zbadała bowiem Justyna Kowalska-Leder, Doświadczenie Zagłady z perspektywy dziecka w polskiej literaturze dokumentu osobistego (Wrocław: Monografie FNP), 2009.

${ }^{7}$ Hans Robert Jauss, „Historia literatury jako wyzwanie rzucone nauce o literaturze”, trans. Ryszard Handke, Pamiętnik Literacki, no. 4 (1972): 275.

${ }^{8}$ Czesław Miłosz, Campo di Fiori, in Poezje wybrane. Selected Poems (Kraków: Wydawnictwo Literackie, 1996), 28.

${ }^{9}$ Tomasz Pietrasiewicz, Żydowskie księozbiory, ksieggarnie, biblioteki, http://teatrnn.pl/leksykon/ artykuly/zydowskie-ksiegozbiory-ksiegarnie-biblioteki/ (acc. 07.04.2018). Taką lubelską ceremonię opisał Józef Czechowicz: „W jednym z okolicznych zaułków stoi niewielki dom modlitwy [...]. Ponieważ budynek był bardzo stary i wymagał przebudowy, w maju roku bieżącego przystąpiono do remontu. Podczas robót okazała się potrzeba przebicia jednej z wewnętrznych ścian. W grubości muru odkryto niszę, która zawierała bezcenny skarb: [...] rękopisy pięcioksięgu Mojżeszowego i innych ksiąg Starego Zakonu, zwinięte w rulonach i zamknięte w bogatych, artystycznie rzeźbionych oprawach. Ponieważ rodały są używane w synagogach jako księgi święte i zarazem przedmioty kultu i to kultu codziennego, fanatyczny tłum żydowski uważał, że rodały z przed wieków, znalezione w niszy i nieużywane - są nieboszczykami. W niedzielę, dn. 7 r.b. ulicami dzielnicy żydowskiej przeciągnął uroczysty pochód pogrzebowy. Bezcenne $\mathrm{i}$ «nieżywe» rodały wieziono na cmentarz izraelicki. Ceremonie pogrzebowe trwały od godz. 10 do $12 \mathrm{w}$ południe" (Józef Czechowicz, Express Lubelski, 11.12.1924, 4. Cit per ibidem). 
Jakie to szczęście: dwaj ocaleńcy [...] spotykamy się na dworcu centralnym wzniesionym na popiołach, oddechach i prochach umarłych [...]

[...] strzępy spalonego papieru, widma listów i książek, unoszące się na prądach wstępujących coraz wyżej i dalej

[...] cienie spalonych książek, rozsypujące się pod dotknięciem $[\ldots]^{10}$.

Intuicyjnie udzielić można kilku wstępnych odpowiedzi na pytanie o motywację dla czytania w tej sytuacji granicznej. Miało charakter ocalający: albo przez sczepienie fabuły z rzeczywistością, w której funkcjonowały dzieci, albo - biegunowo - ich rozszczepienie, spełniało funkcje eskapistyczne, nakładało świat lektury na otaczającą rzeczywistość, przez co pomniejszało poczucie osamotnienia i pozwalało poczuć się częścią szerszej wspólnoty, zaspokajało głód duchowy, przygotowywało na nadchodzące wydarzenia, niekiedy na śmierć, nadawało znamiona sensu temu, co pozbawione było sensu, wypełniało czas.

Dziecięce doświadczenie czytania w getcie istotne miejsce zajmuje we wspomnieniach Alony Frankel, urodzonej 27 czerwca 1937 roku w Krakowie, która wraz ze swoją niereligijną rodziną uciekła do Lwowa, po wkroczeniu tam w 1941 roku wojsk niemieckich znalazła się w getcie, zaś później na wsi i w kryjówce we Lwowie. Ten czas dla niej jako czytelniczki okazał się formacyjny, a książki wówczas poznawane głęboko wyryły się w jej pamięć. Poniższy cytat ukazuje, jakie teksty odkrywała, jakie światy odkrywały jej książki, do jakich „daleko" ją prowadziły, które z nich umożliwiały eksternalizację rzeczywistości, a które ją internalizowały:

Książek, które przeczytałam w dzieciństwie, nie zapominam. Są wypalone w pniu mojego mózgu [...]. Najbardziej byłam dumna z polskich książek, które przeczytałam. Ale czytałam też wiele książek pisarzy francuskich, angielskich, amerykańskich, rosyjskich, czeskich... [...] Jedna z książek opowiadała o głodzie, a ten temat nie był mi obcy. Ktoś powiedział, że Knut Hamsun lubił nazistów. Jaka szkoda! ${ }^{11}$.

Adina Blady-Szwajger, warszawianka, podczas wojny ukrywała się po aryjskiej stronie, pomagała Żydom w szukaniu mieszkań i pracowała jako łączniczka. W I więcej nic nie pamiętam wspominała jeden dzień z czasu okupacji, spoza getta:

- O co chodzi, Mirka? [...] No, mów szybciej, śpieszę się.

- Chciałabym coś do czytania. Tu nic nie ma! - wyjąkała wreszcie.

[...] nie mogłam jej odmówić. To była mądra, inteligentna dziewczyna. Książki były jej potrzebne do życia jak chleb.

${ }^{10}$ Ryszard Krynicki, Jakie to szczęście, in Magnetyczny punkt. Wybrane wiersze i przekłady (Warszawa: Wydawnictwo CiS, 1996), 135.

${ }^{11}$ Alona Frankel, Dziewczynka, trans. Leszek Kwiatkowski (Warszawa: nisza, 2007), 200-201. 
- Przyniosę, na pewno.

Nawet udało mi się dotrzymać słowa. Kilkakrotnie dostarczałam jej po parę książek kupionych w antykwariacie ${ }^{12}$.

Ów obraz pozwala zasygnalizować poświadczaną w dokumentach osobistych i w tekstach literackich głęboko zakorzenioną w żydowskiej kulturze potrzebę czytania. W gettach funkcjonowały także ruchome biblioteki (tzw. bookmobile znane były w Wielkiej Brytanii, Stanach Zjednoczonych czy w Niemczech już u początku XX wieku). Z księgozbiorów Centralnej Biblioteki dla dzieci, powstałej w listopadzie 1940 roku, korzystało około pięćdziesięciu instytucji, wśród nich np. szpital dziecięcy. Zwykle ich przedstawiciele wymieniali większą liczbę tomów: „Istniał również ważki problem czystości. Bardzo często książki wracające z punktów dla uciekinierów lub z innych miejsc nędzy były zawszone. Należało je natychmiast dezynfekować albo nawet spalić"13. Podstawę do wyobrażenia sobie takich objazdowych bibliotek dają zapisy Stanisława Adlera: „Żydom nie wolno korzystać $\mathrm{z}$ bibliotek, a wszelkie biblioteki prowadzone przez Żydów zostają skonfiskowane. Części z nich udaje się jednak ukryć swoje księgozbiory. Odbywają się wymiany książek w domach i krążyły biblioteki objazdowe. Getto jest zaczytane Cyganami i Inwazja 1914 Van der Meerscha"14.

\section{Książki-matryce i moc głuszenia kroków. Bezseność Jutki i twórczość Uri Orleva}

W ilustrowanej książce dla dzieci Bezsenność Jutki, napisanej przez Dorotę Combrzyńską-Nogalę, Dawid Cwancygier opowiada wnuczce o Dedalu i Ikarze. Ta, słuchając o uwięzieniu Minotaura, rozmyśla o własnej sytuacji i w antycznym labiryncie dostrzega archetypiczną budowlę zamknięcia (locus horridus):

- Kreta - podjął opowieść - jest grecką wyspą. I tam miał swój pałac król Minos. Mówiłem ci już, że wezwał Dedala, żeby wybudował labirynt dla Minotaura. Dedal przybył na wyspę razem z synem Ikarem.

- Nie miał mamy?

- Nic mi nie wiadomo o mamie.

- Może została w getcie, bo była Żydówką? - domyśliła się Jutka ${ }^{15}$.

${ }^{12}$ Adina Blady-Szwajger, I więcej nic nie pamiętam (Warszawa: Świat Książki, 2010), 181-182 .

${ }^{13} \mathrm{http}: / /$ warszawa.getto.pl/index.ph?pmod=wyszukiwanie_db\&table_id=zdarzenia\&columns $=$ zdarzenie $\&$ show_source $=I I I \%$ C5\%BC2\%20Berm\&lang $=$ en $($ acc. 07.04.2018).

${ }^{14} \mathrm{http}: / /$ warszawa.getto.pl/index.php?mod=wyszukiwanie_db\&table_id=zdarzenia\&columns =zdarzenie\&show_source $=$ Iop1,\%20Adler (acc. 07.04.2018).

${ }^{15}$ Dorota Combrzyńska-Nogala, Bezsenność Jutki, il. Joanna Rusinek (Łódź: Wydawnictwo Literatura, 2012), 41. 
Obserwujemy tu dwukierunkowe oddziaływanie mitu, dziewczynka balansuje na nieostrej granicy między mitem antycznym a współczesną historią. Nakłada bieżącą maskę na wydarzenia mityczne, usiłuje zrozumieć opowieść o Dedalu i Ikarze, projektując na nią własną sytuację. Ale nakłada również mityczną matrycę na bieżące wydarzenia. W miejscu opowieści, w którym następuje upadek Ikara, reaguje: „I strażnik go zestrzelił [...]”16. Prosi też, by dziadek zbudował dla nich takie skrzydła. Gdy się to stanie, „polecimy do Szwajcarii jak pani Sara Singer. [...] Zupełnie jak mój gawron" ${ }^{17}$.

Motyw ptaka-anioła pojawia się także we wspomnieniach Uriego Orleva, którego - jak mówił w wywiadzie - matka przygotowywała: „Dzieci, być może będziemy musieli wyjść na dach i skoczyć. Staniemy się wtedy aniołami”18. Orlev, urodzony w 1931 roku jako Jerzy Henryk Orłowski, przed wojną mieszkał z rodziną na Żoliborzu. Z matką i młodszym bratem znalazł się w getcie. Matka została zastrzelona przez gestapowca, po tym ciotka ukryła chłopców po aryjskiej stronie.

Anna Nasalska napisała o wadze książek w domu Orłowskich: „Jeśli zawsze stanowiły główny składnik dzieciństwa autora i ulubione zajęcie, to w złych czasach niosły ocalenie" ${ }^{\prime 19}$. Na unikalny wgląd w temat artykułu pozwala wykład Orleva zatytułowany Ksiażki mojego dzieciństwa (1931-1945). Wspomina w nim zdanie z Osobowości ocalałego Ala Sieberta: „Jedną z najważniejszych cech osoby, która potrafi poradzić sobie w trudnych sytuacjach, jest ciekawość" (UO, 9). Ta formuła definiuje jego wojenną przemożną potrzebę czytania ${ }^{20}$.

${ }^{16}$ Ibidem, 43.

${ }^{17}$ Ibidem, 53.

18 „Nie mogę znaleźć w sobie nienawiści. Z Urim Orlevem rozmawia Agnieszka Zagner”, Polityka, 04.07.2011, https://www.polityka.pl/tygodnikpolityka/spoleczenstwo/1517204,1,izraelskipisarz-uri-orlev-dla-politykapl.read (acc. 07.04.2018).

${ }^{19}$ Uri Orlev, Książki mojego dzieciństwa (1931-1945), trans. Jan Rybicki, posłowie Anna Nasalska (Lublin: Wydawnictwo Uniwersytetu Marii Curie Skłodowskiej, 2012), 34. Dalej posługuję się skrótem UO i wskazuję numer strony.

${ }^{20}$ Miał jako dziecko w getcie wiele powodów do płaczu, w odczycie Książi mojego dzieciństwa przywoływał jednak taką sytuację:

„[...] raz jeszcze płakałem w getcie $\mathrm{z}$ innego powodu. O książkę. Było to w moje urodziny w 1941 albo 1942 roku. Mama zapytała, jaki chcę dostać prezent. Powiedziałem, że marzę o wierszach Mickiewicza. [...] Księgarz pokazał nam tom poezji zebranych Mickiewicza, duży, w czerwonej okładce, z wytłoczonym - nie wymalowanym - profilem poety. Wyczuwało się go pod palcami.

Mama zapytała:

- Ile pan chce?

A pan odpowiedział:

- Piętnaście złotych.

- No nie, to za drogo - powiedziała. Wyszliśmy.

Kiedy znaleźliśmy się na ulicy, mama spojrzała na mnie i spytała:

- Jurek, dlaczego płaczesz? No dobrze, chodź, kupię ci tę książkę" (UO, 13). 
Czytelniczą akuszerką stała się dla chłopców matka (,„[...] zapalała świeczki albo lampę naftową. Siadaliśmy w trójkę przy dużym stole i mama czytała nam różne książki. [...] zapamiętałem Cudowna podróż Selmy Lagerlöf”, UO, 12). Dwa tytuły zajmowały w jego życiu w getcie szczególne miejsce. Na cześć Robinsona Crusoe nazwał generała swojej wyimaginowanej armii, w której wszyscy żołnierze nosili książkowe imiona. Konsekwentnie ją rozbudowywał:

Z powieści [Jamesa Fenimore'a - przyp. aut.] Coopera pochodził między innymi mój generał Ostatni Mohikanin. Miałem też generała Gordona - ale oczywiście nie był to Aharon Dawid Gordon, pionier syjonizmu, tylko ten dzielny Anglik, którego zaciągnąłem do mojego wojska po przeczytaniu $W$ pustyni $i$ w puszczy. [...] Długo nie mogłem wybaczyć bratu, że podebrał mi generała Robin Hooda. Zaklepał go sobie, choć nie przeczytał książki, tylko zapamiętał go z opowiadań mamy. [...] I choć zaklepałem sobie Don Kichota, brat przechytrzył mnie, bo zaklepał Sancho Pansę. Na to też nie mogłem się zgodzić, ale tym razem obeszło się bez bójki: Sancho Pansa został wymieniony za Obieżyświata Juliusza Verne'a [UO, 16].

W zacytowanym poniżej fragmencie ujawni się tytuł książki odbieranej przez chłopca w trybie alegorycznym i znajdującej przedłużenie w jednej z fabuł stworzonych przez niego wiele lat po wojnie.

Mama, kiedy jeszcze była razem z nami, często usiłowała namówić mnie na książki, które
sama uwielbiała w dzieciństwie - albo przynajmniej takie, które nie były „straszne”, czyli,
według mojej oceny, „dla dziewczynek”. Udało jej się przekonać mnie do książek Ericha
Kästnera [...]. Ale jako że mama czytała nam w długie, zimowe wieczory taką właśnie grubą
książkę „,dla dziewczynek” o cudownych przygodach małego Nilsa i dzikich gęsi - do dziś
wspomnienia o matce mieszają mi się czasem z wieczorami z tą książką i to mimo tego, że
Nils nie miał szans zostać jednym z naszych generałów.
[...] I jeszcze na jedną książkę namówiła mnie mama: na Bambi [...] Feliksa Saltena. Zacząłem
czytać, bo chciałem mamie zrobić przyjemność, ale potem nie mogłem się oderwać od lek-
tury [...] [UO, 17].

Historia ta stanie się dla mnie punktem węzłowym opowieści o książkach gettowych Orleva i pozwoli skoncentrować się na aspekcie wielokrotnego przylegania innych tytułów do owych pierwszych intensywnych lektur w sytuacji in extremis. W jelonku należy dostrzec małego Jurka, a polowaniu - wojnę. Izraelski pisarz wspominał:

Czytałem ją w kółko, bardzo powoli, i w końcu zacząłem wierzyć, że to jakieś dzieło prorocze. Wielkie polowanie w książce nasuwało myśl o toczącej się wokół wojnie i o tym, co potem zaczęto nazywać Holokaustem. Ja i moja mama to Bambi i jego mama [UO, 18].

Już to byłoby dość ciekawe. Ale tu zbliżamy się do szczególnego zapętlenia i przedłużenia gettowej lektury, również do autorskiej czytelniczej epifanii, tak dojmującej, że trzeci z epigrafów - z Odpowiedzi Herberta - znalazł się 
$\mathrm{w}$ artykule w związku z tym jednym fragmentem. Feliks Salten, austriacki pisarz żydowskiego pochodzenia, zmarły w Zurychu w 1945 roku, opowieść o Bambi opublikował w roku 1923. W 1936 roku Hitler zakazał rozpowszechniania jego utworów. Na jednej z pierwszych stron matka instruuje młodego jelonka:

Iść na łąkę to rzecz nie tak prosta [...] jest to rzecz bardzo trudna i niebezpieczna. [...] Ja wyjdę najpierw sama, a ty stój tutaj i czekaj. [...]. Ani na chwilę nie spuszczaj ze mnie oka. Kiedy zobaczysz, że biegnę z powrotem, na to miejsce, gdzie teraz jesteśmy, wówczas zawrócisz natychmiast i uciekniesz, jak będziesz mógł najszybciej. [...] W każdym razie biegnij, biegnij, ile sił... Biegnij, nawet gdyby się coś stało... nawet, gdybyś widział, że ja... że ja padam na ziemię ...nie zwracaj na mnie uwagi, rozumiesz?... Cokolwiek byś widział albo słyszał ...uciekaj stąd, uciekaj, jak możesz najszybciej...! Czy przyrzekasz mi to? ${ }^{21}$.

Czytelnik książki Orleva Biegnij chłopcze, biegnij (zainspirowanej głównie wspomnieniami Yorama Friedmana, który przybrał fałszywą tożsamość Jurka Staniaka) przypomina sobie zapewne, że jej bohater Srulik jako ośmiolatek razem $\mathrm{z}$ rodzicami trafia do warszawskiego getta; ojciec zbiega, zaś matka pewnego dnia znika. Od tej pory Srulik-Jurek radzi sobie sam. Jak Bambi w opowieści. I jak Bambi od matki w zacytowanym wyżej fragmencie, on od ojca słyszy podobny instruktaż: by biegł szybko, przed siebie i starał się zmylić trop. Tytułowe słowa „Biegnij, chłopcze [...] biegnij” ${ }^{22}$ w książce wypowiada matkująca Jurkowi gospodyni. Na stronie sąsiedniej przeczytamy: „Srulik wrócił do lasu i wydawało mu się, że las także cieszy się z jego powrotu. [...] Nauczył się skradać cicho jak leśne zwierzęta, które obserwował"23. Pisząc te fragmenty i ów z kolejnej strony, autor Wyspy na ulicy Ptasiej musiał głęboko zaglądać w oczy jelonkowi z lektury lat wojennych: „Później pojawiła się sarna z koziołkiem. [...] Nagle zwierzęta skoczyły i zniknęły w mgnieniu oka"24. Trzydzieści stron dalej izraelski autor opisuje leśne spotkanie, anagnorisis Srulika i ojca oraz pamiętny instruktaż, jaki chłopiec od niego usłyszy, będący wiernym odwzorowaniem wskazówek matki-sarny: „Jeśli będą cię ścigać z psami, wejdź do wody albo na bagna, wtedy psy stracą trop" ${ }^{25}$. „Ojciec podniósł się i zaczął biec. [...] Niemcy zaczęli coś krzyczeć. Całe ciało Srulika sprężyło się do ucieczki" ${ }^{26}$.

${ }^{21}$ Feliks Salten, Bambi. Opowieść leśna, il. Mirosław Pokora, trans. Marceli Tarnowski (Warszawa: Alfa, 1987), 12.

${ }^{22}$ Uri Orlev, Biegnij chtopcze, biegnij, trans. Magdalena Sommer (Warszawa: Wydawnictwo W.A.B., 2013), 54.

${ }^{23}$ Ibidem, 55.

${ }^{24}$ Ibidem, 57.

${ }^{25}$ Ibidem, 84.

${ }^{26}$ Ibidem, 85 . 


\section{Książki pierwsze jako książki ostatnie. Czytać wszystko - i zdążyć}

Sara Zyskind (ur. w Lodzi w 1927 roku, zm. w Tel Awiwie w 1994 roku) obok lektury Nędzników wspomina wiersz Marii Konopnickiej:

Nasze oczy napełniały się łzami, gdy wciąż od nowa zagłębiałyśmy się w poemat Słoneczko, w którym sierota oskarża jasno świecące słońce, że jest tak bardzo obojętne na ludzkie cierpienia. Słońce odpowiadało, że ono nie ma $\mathrm{z}$ tym nic wspólnego - że to jest zmartwienie niebios. Jego zaś obowiązkiem jest nadawanie światu radosnego wyglądu, opromieniając go blaskiem $^{27}$.

Janina Katz w Moim życiu barbarzyńcy przywołała inny utwór noszący taki sam tytuł:

Poczytałam trochę baśnie braci Grimm, ale wydały mi się jeszcze bardziej przerażające niż życie; pocieszyłam się inną książką, Słoneczkiem.

Słoneczko opowiadało o cudownej historii pewnej jasnowłosej dziewczynki, której matka zachorowała. Słoneczko robiła wszystko, co tylko mogła, żeby matka wyzdrowiała. I zasnę$\operatorname{lam}^{28}$.

Mowa tu o książce Marii Buyno-Arctowej, żony wydawcy Zygmunta Arcta, której bohaterka, Marysia, jako sierota trafia do domu przyjaciółki zmarłej matki, pani Dębskiejej. Magdalena Jonca dostrzegła w opowieści studium nad głębią sierocej duszy ${ }^{30}$. Rzadko zdarza się sięgnąć po wspomnienia tych, którzy przetrwali Zagładę jako dzieci, i nie spotkać choćby passusu poświęconego zachłannemu czytaniu. Książka Janiny Katz nie uchyla się od tej prawidłowości:

Czytałam nocami. Ciągle jeszcze spałyśmy z Lolą w jednym łóżku, ale dostałam latarkę. Byłam opętana przez książki i czytałam wszystko, co mi wpadło w ręce. Książki dla dzieci i młodzieży dostawałam od Loli: Anię z Zielonego Wzgórza Lucy Maud Montgomery, Serce Amicisa, Pinokia i cudowną Zielono mam $w$ głowie. [...] Były też inne książki: Sinclaira Lewisa i Jacka Londona, którzy opisywali i krytykowali stosunki kapitalistyczne. I Quo vadis Sienkiewicza, pisarza, rzecz jasna, religijnego i konserwatywnego, ale laureata Nagrody Nobla, zaliczanego do polskich klasyków ${ }^{31}$.

${ }^{27}$ Sara Zyskind, Skradzione lata, trans. Anna Wiśniewska-Walczyk (Warszawa: Czytelnik, 1991), 14.

${ }_{28}^{28}$ Janina Katz, Moje życie barbarzyńcy, trans. Bogusława Sochańska (Warszawa: Jacek Santorski \& Agencja Wydawnicza, 2006), 105.

${ }^{29}$ Maria Buyno-Arctowa, Stoneczko (Warszawa: Nasza Księgarnia, 1958).

${ }^{30}$ Magdalena Jonca, Sierota $w$ literaturze polskiej dla dzieci $w$ XIX wieku (Wrocław: Wydawnictwo Uniwersytetu Wrocławskiego, 1994), 283.

${ }^{31}$ Ibidem, 126. 


\section{Czarne sezony - książki nieczytane za młodu}

Michał Głowiński fragment Czarnych sezonów zatytułował: Książki, których nie czytatem za mtodu.

Wiedziałem, że moja opowieść negatywna o tym, czego za młodu nie czytałem, z konieczności książek by nie dotyczyła. [...] gdy [...] moi koledzy - rówieśnicy i trochę starsi - wspominali z sentymentem swe wczesne lektury, byłem skazany na milczenie, nie miałem o czym mówić. [...] Muszę przyznać, że ich wspominków o niegdysiejszych lekturach słuchałem nie bez zazdrości, myślałem o tym, co mnie w dzieciństwie ominęło $[\ldots]^{32}$.

Po piętnastym roku życia czytał francuskiego powieściopisarza i kojarzył wykreowany w jego powieściach świat $\mathrm{z}$ tym znanym $\mathrm{z}$ warszawskiego getta:

Wpadła mi w ręce któraś z powieści Victora Hugo - i mnie zafascynowała. Rzuciłem się na inne jego utwory; odpowiadały mi one może dlatego, że tak dużą rolę grają w nich relacje o różnych okrucieństwach. Pod pewnymi względami nakładały się na to, co stało się moim doświadczeniem ${ }^{33}$.

Dokładnie przeczytał Czarne sezony Marcin Szczygielski, autor powieści dla młodzieży Arka czasu, czyli wielka ucieczka Rafała od kiedyś przez wtedy do teraz $i$ wstecz, ujawniającej związki ze świadectwami osobistymi. Poprzedza ją motto z Wehikułu czasu Herberta George'a Wellsa, a zatem książki, która wskrzeszała odczucie ze świata poza murami i której pierwsza wersja nosiła tytuł Chroniczni argonauci $^{34}$. Byli nimi też mali czytelnicy w gettach.

Bohater utworu Szczygielskiego to chłopiec adaptujący się dzięki czytaniu do codziennej katabazy. Wypożycza książki z jednej z bibliotek w getcie. Barbara Engelking wyróżniła 24 takie placówki, w tym aż dziesięć przy ulicy Leszno. Szczygielski wspomniał bibliotekę przy ulicy Leszno 67, scharakteryzowaną przez badaczkę jako: „Centralna biblioteka Centosu dla dzieci, kierowniczka: Barbara Berman. Od jesieni 1941 nosi imię Rozy Symchowicz (psycholożki i pedagożki zmarłej w 1941 roku, która w getcie roztaczała opiekę nad najbiedniejszymi dziećmi - przyp. aut.). W grudniu 1941 znajdowało się tam 1300 książek polskich i żydowskich, miała ponad 700 stałych czytelników"35.

\footnotetext{
${ }^{32}$ Michał Głowiński, Czarne sezony, 156.

${ }^{33}$ Ibidem, 164.

${ }^{34}$ Herbert G. Wells, Wehikut czasu, trans. Feliks Wermiński (Wrocław-Warszawa-Kraków: Zakład Narodowy im. Ossolińskich, 1985), XXXIX.

${ }^{35}$ Barbara Engelking, Jacek Leociak, Getto warszawskie. Przewodnik po nieistniejącym mieście (Warszawa: Stowarzyszenie Centrum Badań nad Zagładą Żydów, 2013), 585. Interesujący artykuł poświęcony bibliotekarzowi z getta wileńskiego zaproponował z kolei Zbigniew Gruszka: „Herman Kruk (1897-1944) jako organizator i dyrektor biblioteki getta wileńskiego: szkic do obrazu bibliotekarstwa żydowskiego w Polsce”, Acta Universitatis Lodziensis, no. 16 (2010), 171-182.
} 
Bohater instruował: „Tu trzeba wejść na podwórko otoczone kamienicami, wbiec po schodach na górę i jest się na miejscu. W bibliotece" ${ }^{\text {36 }}$.

Patrzą na mnie, uśmiechają się i sądzą, że skoro jestem taki mały, to muszą [...] dać mi coś cienkiego z obrazkami, a kiedy się upieram, że nie chcę, to w ostateczności proponują Doktora Dolittle. Nie mam nic przeciw Doktorowi Dolittle, bardzo mi się podobał. Ale to było kiedyś, [...] gdy jeszcze nie miałem nawet siedmiu lat. Teraz przeczytałem właśnie Dwa lata wakacji Juliusza Verne'a, to bardzo gruba książka i wcale nie dziecinna, chociaż opowiada o dzieciach [MS, 11].

Kiedy wypożycza egzemplarz Wehikułu czasu Wellsa, pogrąża się w lekturze:

[...] jestem już na czterdziestej siódmej stronie, zaraz na początku rozdziału Zmierzch ludzkości. Za nic nie mogę się oderwać i czuję, że mam wypieki na policzkach ${ }^{37}$.

Dziadek głównego bohatera pracował przed wojną jako muzyk w filharmonii. W getcie zarabia na ich życie, grając na skrzypcach w teatrach lub na spotkaniach towarzyskich. Michał Głowiński w Czarnych sezonach także wspominał ulicznego grajka, mijanego przezeń w drodze na komplety:

Gdy chodziłem na komplety prowadzone przez pannę Julię i panią Bronisławę, napotykałem na swej [...] trasie niemłodego, wychudzonego człowieka grającego na skrzypcach. Wykonywał on zawsze tę samą melodię, od kogoś z dorosłych dowiedziałem się, że to fragment Koncertu skrzypcowego Mendelssohna. Mówiło się, że skrzypek ów był przed wojną członkiem orkiestry Filharmonii Warszawskiej, to dopiero gettowa nędza wygnała go na ulicę. Mam wciąż przed oczyma jego postać. Było go tak niewiele, że niknął w obszernym szarym płaszczu, który zapewne za dobrych przedwojennych czasów był dopasowany, a teraz na nim wisiał [...]. Wszystko, co się z nim wiązało - poza melodią, którą wydobywał ze swych skrzypiec - łączyło się z szarością, a więc było zharmonizowane z ogólnym kolorem getta ${ }^{38}$.

\section{Inicjacja w śmierć - Poczta}

Książka Adama Jaromira i Gabrieli Cichowskiej Ostatnie przedstawienie panny Esterki fabularyzuje historię wystawienia przez Esterę Winogronównę i Janusza Korczaka sztuki Poczta Rabindranatha Tagorego. Stary Doktor - bohater opowieści - myśli: „Może ta właśnie bajka zdoła nadać temu życiu jakiś sens

${ }^{36}$ Marcin Szczygielski, Arka czasu, czyli wielka ucieczka Rafała od kiedyś przez wtedy do teraz $i$ wstecz, il. Daniel de Latour (Warszawa: Wydawnictwo Piotra Marciszuka STENTOR, 2013), 10. Dalej, cytując tę pozycję, stosuję skrót MS i wskazuję numer strony.

${ }^{37}$ Ibidem, 34.

${ }^{38}$ Michał Głowiński, Czarne sezony, 13. 
i przygotować dzieci do tej długiej, dalekiej i niebezpiecznej podróży"39. Jej bohater, Amal/Omol, przesiaduje w oknie i rozmawia z przypadkowymi przechodniami: ,[...] lekarz zabronił mi wychodzić. Mnie nigdy nigdzie nie pozwolą wyjść!”40. „Dokąd zabierzesz? Daleko? Za te góry”41 - pyta strażnika, marząc, jak inne dzieci, o swoim „daleko”, wspomnianym we wstępnie artykułu. Chłopiec spełnia się w świecie wyobraźni. Podobne spełnienie miało zdarzyć się lipcowego popołudnia 1942 roku w Domu Sierot. Autorzy książki odtwarzają taką scenę:

- Opaska! - przypominam sobie nagle. - Zostawiłam ją na dole.

Jednak panna Esterka mnie powstrzymuje.

- Dzisiaj nie będzie Ci potrzebna.

- Tutaj - mówi, wskazując na linię, gdzie zaczyna się scena - tutaj są już Indie.

Ryszard Waksmund pisał, że śmierć przestała być w sztuce Tagorego tematem tabu; przestała nim być także w Domu Sierot. Przedstawienie w sierocińcu Janusza Korczaka odbyło się w sobotę, 18 lipca 1942 roku, o godzinie 16.30. Zaproszenie na nie znaleziono w pierwszej części Archiwum Oneg Szabat. Widnieją na nim słowa Władysława Szlengla:

Coś więcej niż tekst - bo nastrój,

Coś więcej niż emocja - bo przeżycie,

Coś więcej niż aktorzy - bo dzieci ${ }^{42}$.

5 sierpnia 1942 roku, trzy tygodnie po wystawieniu Poczty, mieszkańcy sierocińca zostali zgładzeni. Hanna Mortkowicz-Olczakowa w biografii Janusz Korczak przypomniała jeden z najpóźniejszych tekstów Starego Doktora, nowelkę O trzech wyprawach Herszka, w której

obłąkany rebe opowiada małemu żydowskiemu dziecku bardzo ponurą legendę o zagładzie Żydów. „Była wojna i Tytus spalił świątynię. Tak, tak. Pożar był. Paliły się książki Boga, Tak, tak. Ale nie. Palił się tylko papier, a litery frunęły do nieba i żyją"43.

Wystawienie sztuki indyjskiego autora miało charakter inicjacji w śmierć, stało się teatralną ceremonią oddziałującą na psychikę dzieci, zaś dorosłym widzom umożliwiło uruchomienie symbolicznego stylu odbioru.

\footnotetext{
${ }^{39}$ Adam Jaromir, Gabriela Cichowska, Ostatnie przedstawienie panny Esterki (Poznań: Media Rodzina, 2014).

${ }^{40}$ Rabindranath Tagore, Poczta, trans. Bogdan Gębarski, posłowiem opatrzył Ryszard Waksmund (Wrocław: Wydawnictwo Wacław Bagiński, 1997), 19.

${ }^{41}$ Ibidem.

${ }^{42}$ Samuel Kassow, op. cit., 250.

${ }^{43}$ Hanna Mortkowicz-Olczakowa, Janusz Korczak (Warszawa: Czytelnik, 1978), 11.
} 


\section{Zakończenie}

Jednym ze sposobów rozmawiania o wojnie jest uczynienie punktem wyjścia właściwych lektur, desakralizujących ją. Takie książki dorośli wybierali z bibliotek i biblioteczek dla dzieci zamkniętych w getcie (Bambi, Robinson Crusoe). Podjęcie w artykule tematu socjologii literackiej i poetyki odbioru w sytuacji in extremis wymaga ponownego przywołania Michała Głowińskiego, tym razem jako badacza stylów odbioru. Wiele dzieci w gettach uruchamiało styl symboliczny, wydobywało z tekstów ruchome znaczenia, nadpisując im swoją rzeczywistość. To spostrzeżenie wyznacza kierunek dla sformułowania wniosku o niebagatelnym zakresie oddziaływania na młodego odbiorcę, pozwalającym mu zidentyfikować pragnienia i lęki. Lektury umożliwiały zawiązanie wspólnoty i uruchomienie instynktu przetrwania.

Część z nich podyktowana była po prostu zawartością domowych lub sąsiedzkich biblioteczek lub funkcjonujących wypożyczalni i miała charakter dość przypadkowy, ale wiele czytelniczych wyborów płynęło z wyższych przesłanek. Harald Weinrich w klasycznym artykule $O$ historię literatury $z$ perspektywy czytelnika zauważał przecież: „umiejący czytać nie bierze do ręki każdej książki”" lektury intencjonalne pomnażały doświadczenia, pozwalały na utożsamienie z bohaterem; uspokajały zmysły lub pobudzały do intensywniejszego życia w skrajnej sytuacji, sprostały oczekiwaniom relewancji między światem lektury a życiem $\mathrm{w}$ getcie.

\section{Bibliografia}

Blady-Szwajger, Adina. I więcej nic nie pamiętam. Warszawa: Świat Książki, 2010.

Buyno-Arctowa, Maria. Stoneczko. Warszawa: Nasza Księgarnia, 1958.

Combrzyńska-Nogala, Dorota. Bezsenność Jutki. Łódź: Wydawnictwo Literatura, 2012.

Engelking, Barbara, et Jacek Leociak. Getto warszawskie. Przewodnik po nieistniejacym mieście. Warszawa: Stowarzyszenie Centrum Badań nad Zagładą Żydów, 2013.

Frankel, Alona. Dziewczynka, trans. Leszek Kwiatkowski. Warszawa: Nisza, 2007.

Głowiński Michał. Czarne sezony. Warszawa: Open, 1998.

Gruszka, Zbigniew. „Herman Kruk (1897-1944) jako organizator i dyrektor biblioteki getta wileńskiego: szkic do obrazu bibliotekarstwa żydowskiego w Polsce”. Acta Universitatis Lodziensis, no. 16 (2010).

Jaromir, Adam, et Gabriela Cichowska. Ostatnie przedstawienie panny Esterki. Poznań: Media Rodzina, 2014.

Jauss, Hans Robert. „Historia literatury jako wyzwanie rzucone nauce o literaturze”, trans. Ryszard Handke. Pamiętnik Literacki, no. 4 (1972).

${ }^{44}$ Harald Weinrich, „O historię literatury z perspektywy czytelnika”, trans. Ryszard Handke, Teksty, no. 4 (1972): 158. 
Jonca, Magdalena. Sierota w literaturze polskiej dla dzieci w XIX wieku. Wrocław: Wydawnictwo Uniwersytetu Wrocławskiego, 1994.

Kassow, Samuel D. Kto napisze nasza historię. Ukryte Archiwum Emanuela Ringelbluma. Ostatni rozdziat zagłady warszawskiego getta, trans. Grażyna Waluga et Olga Zienkiewicz. Warszawa: Amber, 2009.

Katz, Janina. Moje życie barbarzyńcy, trans. Bogusława Sochańska. Warszawa: Jacek Santorski \& Agencja Wydawnicza, 2006.

Kowalska-Leder, Justyna. Doświadczenie Zagłady z perspektywy dziecka $w$ polskiej literaturze dokumentu osobistego. Wrocław: Fundacja na rzecz Nauki Polskiej, 2009.

Krynicki, Ryszard. Jakie to szczęście. In Magnetyczny punkt. Wybrane wiersze i przekłady. Warszawa: Wydawnictwo CiS, 1996.

Miłosz, Czesław. Poezje wybrane. Selected Poems. Kraków: Wydawnictwo Literackie, 1996.

Mortkowicz-Olczakowa, Hanna. Janusz Korczak. Warszawa: Czytelnik, 1978.

„Nie mogę znaleźć w sobie nienawiści. Z Urim Orlevem rozmawia Agnieszka Zagner”, Polityka, 4 lipca 2011, https://www.polityka.pl/tygodnikpolityka/spoleczenstwo/1517204, 1,izraelski-pisarz-uri-orlev-dla-politykapl.read.

Orlev, Uri. Biegnij chłopcze, biegnij, trans. Magdalena Sommer. Warszawa: Wydawnictwo W.A.B., 2013.

Orlev, Uri. Książki mojego dzieciństwa (1931-1945), trans. Jan Rybicki. Lublin: Wydawnictwo Uniwersytetu Marii Curie Skłodowskiej, 2012.

Pietrasiewicz, Tomasz. Żydowskie księgozbiory, księgarnie, biblioteki, http://teatrnn.pl/ leksykon/artykuly/zydowskie-ksiegozbiory-ksiegarnie-biblioteki/.

Roszak, Joanna. „The Remains of the Letters. Three Reading Paradigms in the Ghettos”. Porównania, no. 21 (2017): 225-241.

Salten, Feliks. Bambi. Opowieść leśna, il. Mirosław Pokora, trans. Marceli Tarnowski. Warszawa: Alfa, 1987.

Szczygielski, Marcin. Arka czasu, czyli wielka ucieczka Rafała od kiedyś przez wtedy do teraz $i$ wstecz, il. Daniel de Latour. Warszawa: Wydawnictwo STENTOR, 2013.

Tagore, Rabindranath. Poczta, trans. Bogdan Gębarski. Wrocław: Wydawnictwo Wacław Bagiński, 1997.

Weinrich, Harald. „O historię literatury z perspektywy czytelnika”, trans. Ryszard Handke, Teksty, no. 4 (1972).

Wells, Herbert G. Wehikut czasu, trans. Feliks Wermiński. Wrocław-Warszawa-Kraków: Zakład Narodowy im. Ossolińskich, 1985.

Zyskind, Sara. Skradzione lata, trans. Anna Wiśniewska-Walczyk. Warszawa: Czytelnik, 1991. 